\title{
Review
}

\section{For Foucault: Against normative political theory}

Mark G. E. Kelly

SUNY Press, Albany, 2018, viii + 193pp.,

ISBN: 978-1-4384-6760-3

Contemporary Political Theory (2020) 19, S44-S47. https://doi.org/10.1057/s41296018-0266-8; published online 19 September 2018

In previous books, Mark Kelly has provided expositions of Foucault's work in general $(2009,2014)$ and of specific texts by Foucault (2013). In this new book, he uses Foucault to analyse the works of other thinkers. The argument that runs through these analyses is that Foucault opposes and offers an alternative to normative political theory, in every sense of that term: he is anti-normative, atheoretical and non-political (meaning that he refuses to offer political programmes or policies). After a short introduction, there are seven chapters each dedicated to a single thinker, with an eighth chapter on Foucault himself. In the chapters on Marx, Lenin, Althusser and Geuss, Kelly shows how these thinkers diverge from normative political thought while nonetheless failing to escape normativity completely; the chapters on Deleuze, Rorty and Honneth do the same whilst also criticising their interpretations of Foucault. The final chapter mostly consists of a critique of Paul Patton's recent claims that the late Foucault embraced normativity.

Although the thread linking the chapters is sometimes faint and loose, reflecting the fact that 'each chapter was originally drafted as an individual essay' (p. 13), the argument is pursued with elegance and consistency, and without any of the pretension and needless obscurity that still characterises much writing in Continental philosophy. The book as a whole makes an important and valuable contribution both to the scholarship on Foucault and to the sub-discipline of political theory.

Its central and most compelling claim is that Foucault is an anti-normative thinker, meaning that he refuses all prescription: while Foucault opposes things (e.g. domination, racism), he offers no normative grounds for this opposition. Foucault's work is rigorously descriptive rather than prescriptive, and 'the opposition follows from analyses of power relations' (p. 149). For example, if we accept Foucault's description of the prison in Discipline and Punish, then we cannot help but reject the prison as an effective form of punishing criminals, for

(c) 2018 Springer Nature Limited. 1470-8914 Contemporary Political Theory Vol. 19, S1, S44-S47 
Foucault has shown us that 'the prison in fact regularly produces criminality as its first effect' (p. 149). To the objection that this anti-normative stance is itself normative - we ought to reject norms - Kelly acknowledges that we could describe Foucault as ascribing to a 'minimally normative anti-normative norm' (p. 99). But even this concession, Kelly argues, only makes sense if we believe that normative thought is natural 'and we must deliberately stop ourselves to prevent us engaging in prescription' (p. 10).

If one really wanted to, it would probably be possible to demonstrate that at some level Foucault remained (crypto)normative, but I'm not sure there would be much point in doing so: it wouldn't tell us much, and it would obscure much that is distinctive about Foucault's work. Kelly convincingly demonstrates both that Foucault's own critiques are without normative bases and that the work of other thinkers such as Marx can be read in non-normative ways. I nonetheless think that Kelly is too prescriptive in proscribing normative thought. It seems to me that normative claims can often be useful and effective: in certain circumstances it may help, for instance, to argue that people should not be enslaved (and not simply that we don't like slavery, or that people whom we thought were free are really slaves), or that the rights and freedoms enjoyed by some should be extended to others. Kelly grants that it may be convenient - albeit, he insists, ultimately unnecessary for activists and social movements to coalesce around shared norms, but argues that political thought can (and should) be undertaken non-normatively (pp. 33, 121). I think this argument depends on a division of political thinkers from political activists that requires greater explanation and justification than Kelly provides.

Although he proceeds on the basis that normative thought should not be considered natural or inevitable, and hence that the 'burden should be on the normativist to explain why normativity is necessary or useful in political thought' (p. 9), Kelly does give us three arguments against normativity. The first is that 'normative commitments restrict the possible audience for political thought to those who share them' (p. 7). I do not find this argument very convincing: surely most normative thought does not simply address itself to those who already share its norms, but, on the contrary, seeks to persuade its audience to accept the norms it proposes (or to recognise that we are already in some way committed to those norms). In this sense, normative thought is not much different from non-normative thought: the former may have to persuade its readers to accept its normative commitments, but the latter will equally have to persuade its readers to accept its interpretation of the facts or its wider methodological commitments. The audience is in both cases 'restricted' to those who share (at least some of) the author's commitments or can be persuaded to accept them.

Kelly's second argument against normativity is that 'normative stances have unintended consequences': normative visions are never realised as intended because the complexity of society means that their effects are unpredictable (p. 8). It is partly for this reason, Kelly argues, that Foucault is anti-political as well as

(C) 2018 Springer Nature Limited. 1470-8914 Contemporary Political Theory $\quad$ Vol. 19, S1, S44-S47 S45 
anti-normative: society is too complex for us to evaluate alternative courses of action, which will all have unforeseeable consequences, and so 'intellectuals should confine their efforts to criticizing' (p. 142), opposing specific relations of power rather than trying to produce 'determinate effects' (p. 145). Against the suspicion that this critical, negative function will be too limited to address global existential threats such as climate change, Kelly maintains that the role of political thought 'can only be to analyze and thereby try to destabilize the strategies of power relations that are coordinating ecosphere destruction' (p. 171).

Kelly's third argument against normativity reinforces the anti-political stance that he attributes to Foucault: normativity is dangerous. To offer a normative vision of the future - to argue that we should adopt a particular course of action or political programme - is to risk being co-opted by power. So, while for Foucault (cited p. 121) 'everything is dangerous', normativity is especially dangerous: 'to imagine another system is to extend our participation in the present system' (Foucault, cited p. 8). Hence, 'attempts to positively determine the goals of politics' are not only unnecessary, they also 'put intellectuals at the disposal of power' (p. 171). In contrast, Foucault's 'critical analyses of power relations cannot easily be made into a tool of power themselves' (p. 8), because they aim to resist specific power relations existing in the present - rather than to affirm new and as yet unrealised power relations whose effects we cannot know.

I suspect it rather flatters most contemporary normative political theory to refer to it as potentially dangerous: irrelevance is probably a greater risk. Perhaps Kelly's weakest claim, however, is that the rejection of normativity entails rejecting 'theoretization' (p. 37), on the basis that 'one cannot have a political theory without some form of normative presupposition' (p. 35). Marx, for example, is praised by Kelly for largely avoiding normative thinking, but is ultimately condemned for offering a theory of capitalism that is normative in its assertion of the inevitability of communism: even though Marx does not claim to know what communism will look like, his 'prognostication outstrips the limits of knowledge' and is therefore dangerous because it can justify any action that will bring about that which Marx claims is 'inevitable' (p. 36). But even if we accept that Marx asserted the inevitability of communism - and this would require greater exegetical work than Kelly here performs - and reject him on that basis, it is not clear that this is a valid reason for rejecting all theory. Even if it is true, as Kelly asserts, that utopian thinking is normative, would it not be possible to theorize without prophesy, and hence without norms?

Later in the book Kelly rejects theoretization not on the basis that it is too normative but because 'articulating a theory dulls your critical edge' (p. 120): the theorist always wants 'to produce a final version' (p. 115), in contrast to the more limited, critical function of the Foucauldian analyst. But the distinction Kelly wants to draw between 'theory' and 'analysis' or 'critique' requires much greater elucidation: what is the threshold beyond which analysis become theory? Foucault 
himself often seemed to be offering something like a theory, perhaps especially in those places where he explicitly denied doing so (e.g. Foucault, 1979, p. 82). We might agree with Kelly's Foucault in refusing 'to produce a totalizing explanation of everything' (p. 11) while nonetheless thinking that certain phenomena - such as capitalism - are complex enough to require a theory to explain them (and, we might add, whose power relations and their effects require a form of resistance more comprehensive than Foucault is able to offer).

While Kelly mounts a lucid and often convincing defence of Foucault, then, that defence is perhaps overzealous. Judged by the standards of Kelly's Foucault, the entire history of political thought is found wanting: we are all - Kelly included 'sub-Foucauldian' (p. 171). Kelly is of course not obliged to criticise Foucault, but Foucault is presumably not a flawless thinker, and it is legitimate to wonder why it is that Kelly has chosen to remain silent about his deficiencies (in the same way that Kelly wonders why Althusser remained silent about Marx's deficiencies [p. 63]). Finally, if I may end on a normative prescription, it ought not to be acceptable in 2018 to write eight chapters on political thinkers and to fail to include any women or non-white thinkers.

\section{References}

Foucault, M. (1979) The History of Sexuality Volume One: An Introduction, trans. R. Hurley. London: Allen Lane.

Kelly, M.G.E. (2009) The Political Philosophy of Michel Foucault. London: Routledge.

Kelly, M.G.E. (2013) Foucault's History of Sexuality Volume I, the Will to Knowledge. Edinburgh: Edinburgh University Press.

Kelly, M.G.E. (2014) Foucault and Politics: A Critical Introduction. Edinburgh: Edinburgh University Press.

Simon Choat

Kingston University, Kingston-upon-Thames KT1 2EE, UK s.choat@kingston.ac.uk 